\section{Components of an innovative electro-control system for undeground mining - analysis}

\author{
Dawid Szurgacz
}

Center of Hydraulics DOH Ltd, Poland

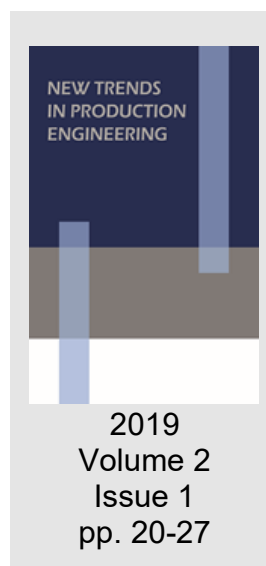

Date of submission to the Editor: 05/2019

Date of acceptance by the Editor: 07/2019

\title{
INTRODUCTION
}

Safety of people in underground mining excavations depends increasingly on the importance of the amount of data in the mine of electronic devices (Figiel, 2014). Due to the high intensity of the operation of machinery and equipment in conditions of a high methane hazard, obtaining the required extraction becomes more and more difficult (Brodny and Tutak, 2016; Brodny and Tutak 2018a). Climatic and ventilation conditions largely limit the mining activity in mining companies (Tutak and Brodny, 2018b; Tutak and Brodny, 2019). One of the main sources of hazards causing accidents at work in mining plants is technical infrastructure, in particular machines and other technical devices. According to data provided by the State Mining Authority in Poland, technical hazards originating from machinery and equipment in 2018 accounted for approximately $50 \%$ of fatal and severe accidents (WUG, 2018). In order to ensure safe use and proper risk assessment, designers of machines and control devices place the greatest emphasis on structural safety aspects (Kasprusz et al., 2013). Requirements related to it are defined in the relevant standards harmonized with the Machinery Directive (Directive, 2006). Nevertheless, due to technical progress, such standards do not exist for most of the currently developed solutions of machine control systems. Therefore, in order to ensure compliance with the essential requirements of the Directive, a set of technical standards was created on functional safety issues, which included the concept of machine safety assessment such as PN-EN 62061 standard (PN-EN 62061, 2008; PNEN ISO 14692-4, 2008) and standard series PN-EN 61508 (PN-EN 62061, 2008). The basis for the activities carried out is the risk assessment, and on the basis of it, the identification of safety functions and the determination of the required safety levels (Szurgacz and Brodny, 2018). It is necessary to solve all security aspects related to the set of devices being developed due to the fact that the system developed within the framework of the project is dedicated to controlling a set of mining machinery, it also enables automatic operation of the longwall system. The electrohydraulic control is one of the latest advances in 
the technique of controlling the powered roof support built into a longwall based on plow or shearer system (Krauze, 2012). The main advantage of this control is the ability to automate the extraction process in the field of powered support, a longwall conveyor, and the possibility of cooperation with master systems controlling the operation of the entire longwall system (Szurgacz, 2018). Significant reduction of the time of moving the powered roof support with the use of electrohydraulic control is one of the basic factors that allow to increase the efficiency and effectiveness of the mining process, while maintaining an appropriate level of safety (Szurgacz, 2018). This is particularly important in the case of thin seams (up to $1.5 \mathrm{~m}$ ) where the solving of a number of technical, ergonomic and economic issues is possible thanks to the automation of the longwall system. It should be emphasized that the exploitation of thin coal seams is of strategic importance for Poland's energy security. Hard coal resources decrease and therefore reaching for coal in thin seams becomes very important or even "a perspective without an alternative". The innovative control system for powered roof support is dedicated to the mining market both for the extraction sector and for producers of equipment for coalface. In particular, it is intended for hard coal mining complexes. However, due to the expected flexibility and the possibility of various system configurations, it can be used in the process of mining other minerals, where mining takes place by a longwall system, and a powered roof support is used as a protection for the excavation. Examples include copper ore mines or potassium salt mines. The development of the hard coal mining industry is determined by the need to increase the efficiency and effectiveness of the mining process while maintaining an appropriate level of safety. The improvement of these indicators can be achieved through the implementation of modern machine constructions enabling the automation of mining processes. One of the fundamental directions of development, both in Polish as well as in the world mining industry, is the automation of the operation of the longwall unit.

Currently manufactured longwall shearers allow to achieve significant mining efficiency at the machine feed speed approaching the value of $10 \mathrm{~m} / \mathrm{min}$. This means that the sections of the powered roof support must be moved within a maximum of 9 seconds for sections $1.5 \mathrm{~m}$ wide and $10.5 \mathrm{~s}$ for sections with a width of $1.75 \mathrm{~m}$. Such switching speeds can not be achieved with traditional, manual control of the powered roof support. To achieve this, especially with the considerable complexity of the support section design, it is necessary to adapt the control hydraulic systems to the large hydraulic fluid flows and to introduce partial or full automation of the section adjustment.

An additional effect of the automation process is the possibility of reducing the number or total elimination of persons controlling the support sections and the possibility of removing the service from the immediate vicinity of the support being moved. In the case of longwalls with plow systems, due to the mining technology, during the movement of the plow, the technical service workers can not stay in the longwall and are transferred to the bottom gate, performing other tasks than in the case of longwalls based on shearer systems. All functions of 
the powered roof support are realized automatically, depending directly on the position of the plow. The only control system that enables the support to work in such conditions is the electrohydraulic control system. Such system is rarely used in the Polish market, due to the financial condition of coal companies and, consequently, the financial condition of mining plants, while limiting the costs of production investments, despite the significant benefits of electrohydraulic control of the powered roof support. The basic criterion determining the resignation of such control when preparing new longwalls, in most cases is the cost of the installation. Research on the elements of the innovative control system has been divided into three basic, interwoven areas: software, control and mechanical design. Requirements for each of these areas are clearly defined.

\section{SOFTWARE}

Data from each section of the innovative electrohydraulic control system of the powered roof support is sent to a longwall computer. Data on the surface of the mine are sent via a connecting line. Data transmission takes place every second. With large systems or difficult conditions, the refresh time of data can be extended to the time necessary for proper data transmission over the communication lines. Data visualization regarding the current state of the production process is displayed on the underground and surface computer. The functions controlling the support section are performed up to several times a day. The operations performed on the section last no longer than a minute, and during the remaining time the support is not supported. Some measurement values remain unchanged during this time, others change slowly.

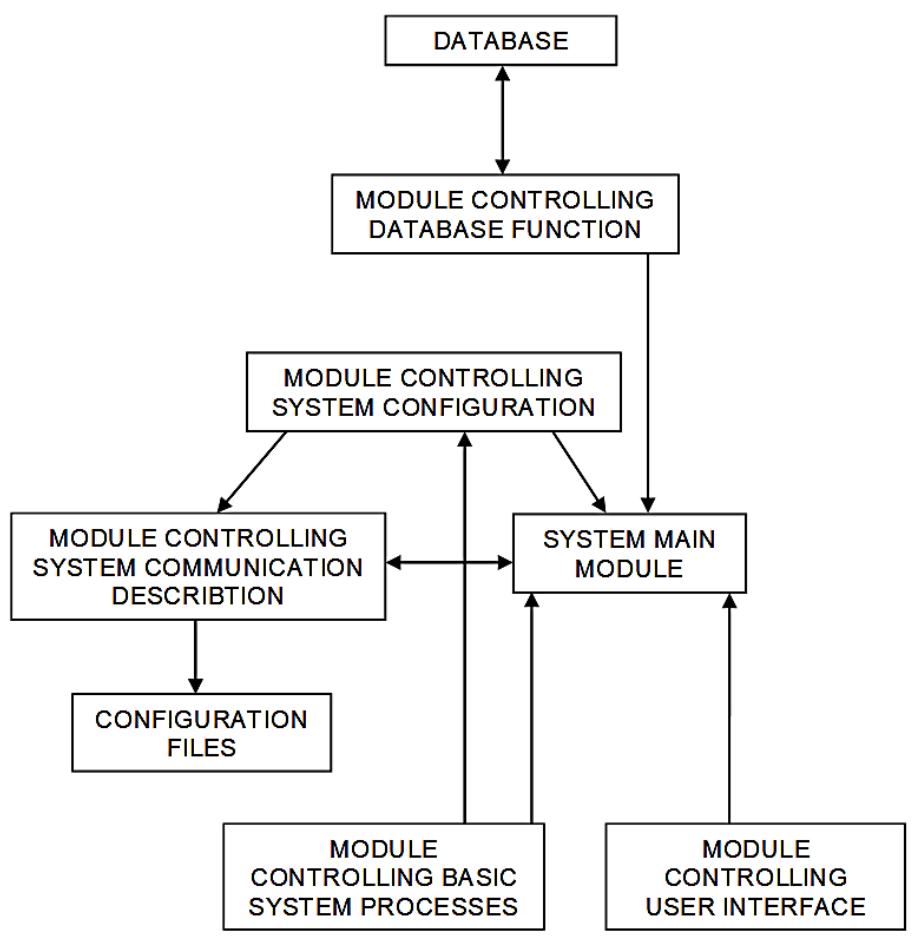

Fig. 1 Software structure 
The data from the system may be irregularly or incomplete due to turning off the power supply in the longwall, driver or power supply failure, mechanical interruption of the communication interface, etc. The database has been designed so as not to lose any information - despite incomplete data. Figure 1 shows the system software structure.

Data from the database are also used to create reports on the work of the powered support, diagnostics of some elements of the section, two- and threedimensional diagrams, etc. Therefore, data viewing is possible according to different types of filters for a given measurement in one section, for all measurements single sections, or for the entire longwall in the required period of time, etc. The data will be stored from the entire longwall run. Figure 2 shows a screenshot of the reporting module.

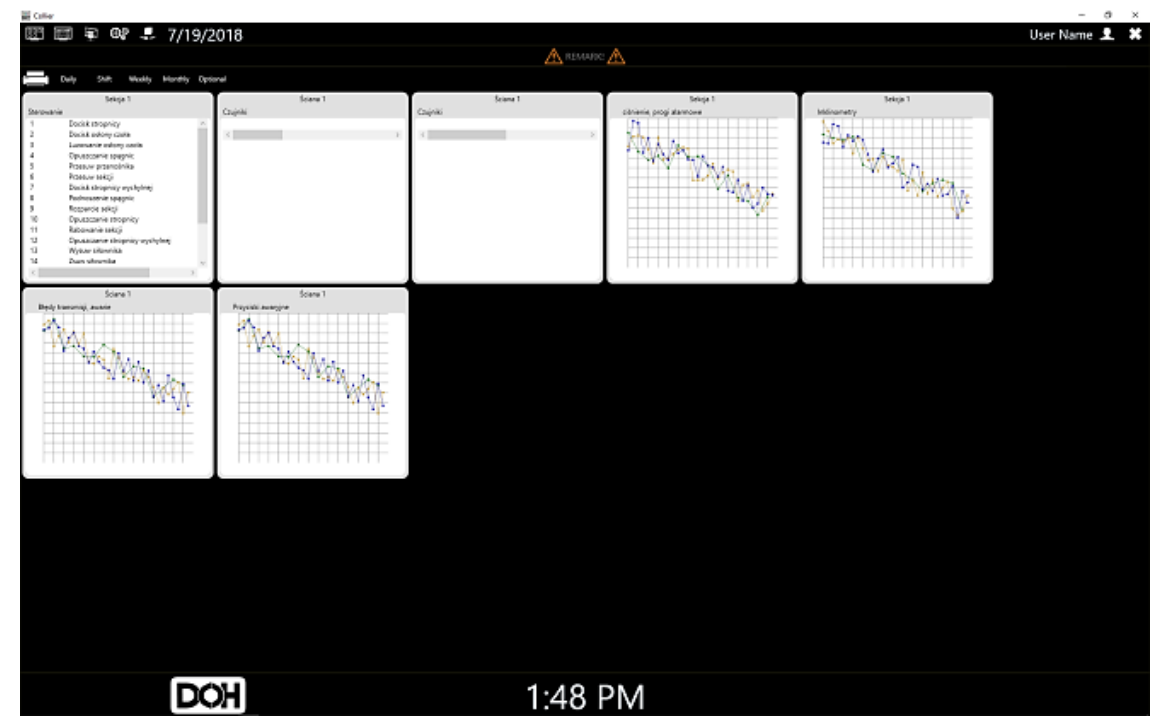

Fig. 2 Reporting module on the work of the powered roof support

\section{LABORATORY TESTS}

In order to verify theoretical considerations, a laboratory model for the electrohydraulic control system of the powered roof support was built. The main research problem encountered was to verify the properties of the electrohydraulic controller module in the case of changing working conditions. Three assumptions were made; the minimum value of the voltage needed to drive the solenoid was determined, the minimum value of the control voltage was determined, the effect of the parameters was generated by the PWM signal. In addition, the effect of coil distance and power supply voltage drop on the received device parameters was found. In the hypothesis, the device should enable the induction of voltage on the receiving side in the range of $12-14 \mathrm{~V}$, at the supply voltage of the sending end of $12 \mathrm{~V}$. The distance between the sending and receiving coils should be in the range of 2 to $2.5 \mathrm{~mm}$. Increasing the distance or decreasing the supply voltage will result in a decrease in the system's properties. In addition, the station is equipped with a PC with software and measuring instruments. The module was controlled using a specially prepared application of the Wireless Valve Control v1 type installed on the computer. The 
main part of the prepared system are magnetically coupled coils. The simplest coil construction was adopted in the tests. In order to ensure a proper distance between the coils, they were placed with the help of epoxy glue to the element of the support. The gaps between the support elements were eliminated by means of clamping.

The course of the preliminary experimental tests in which it was assumed to determine the minimum value of the voltage needed to drive the solenoid valve, for which the solenoid valve will meet its properties, and the minimum time of full control has been determined. The research was as follows:

- setting the voltage supplying the sending end to $12 \mathrm{~V}$,

- actuating the valve outlet,

- observation of whether the pusher has been actuated.

The following values were measured:

- power supply voltage of the sending end,

- supply voltage of the receiving end,

- coil current,

- the supply voltage has been reduced by $0.5 \mathrm{~V}$,

- distance of 2.0-2.5 mm between the coils,

- module and receiver board placed away from the coils,

- coil glued on epoxy glue.

- Unconnected coils - coils of the transmitting and receiving side wound at variance.

The results from the obtained measurements are presented in the Figures (35), below and in Table 1.

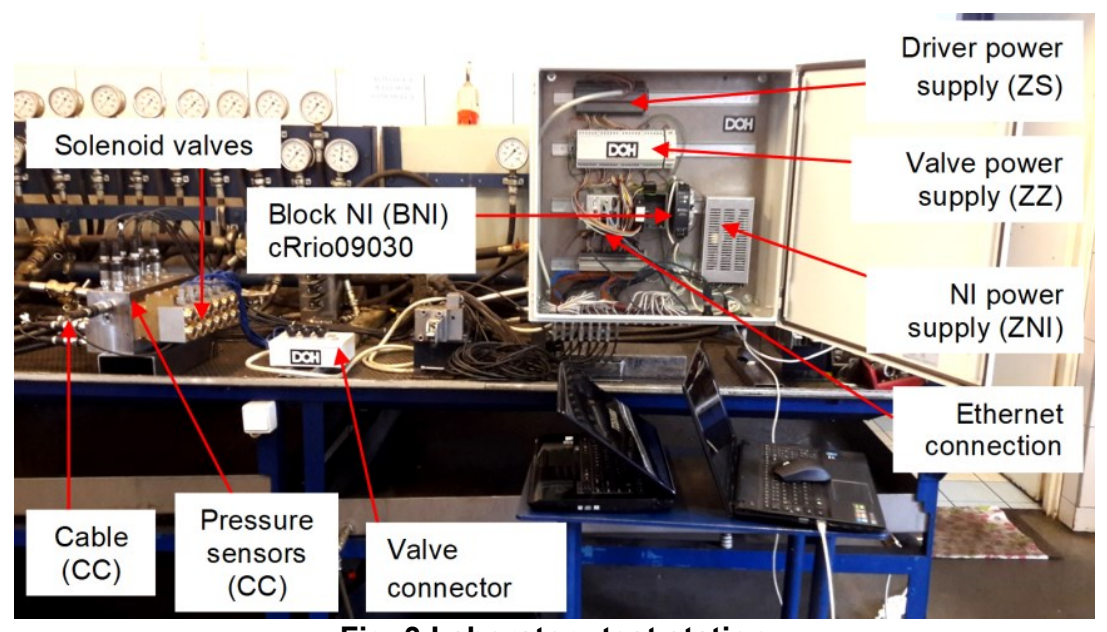

Fig. 3 Laboratory test station

Table 1 Results from the measurements

\begin{tabular}{|c|c|c|}
\hline Sending end & 9 V power supply & 12 V power supply \\
\hline Mode & Power consumption [mA] & Power consumption [mA] \\
\hline Idle & 3 & 3 \\
\hline Start & 182 & 235 \\
\hline Latching & 48 & 67 \\
\hline Receiving end & 9 V power supply & 12 V power supply \\
\hline Mode & Power consumption [mA] & Power consumption [mA] \\
\hline Start & 96 & 125 \\
\hline Latching & 41 & 59 \\
\hline
\end{tabular}




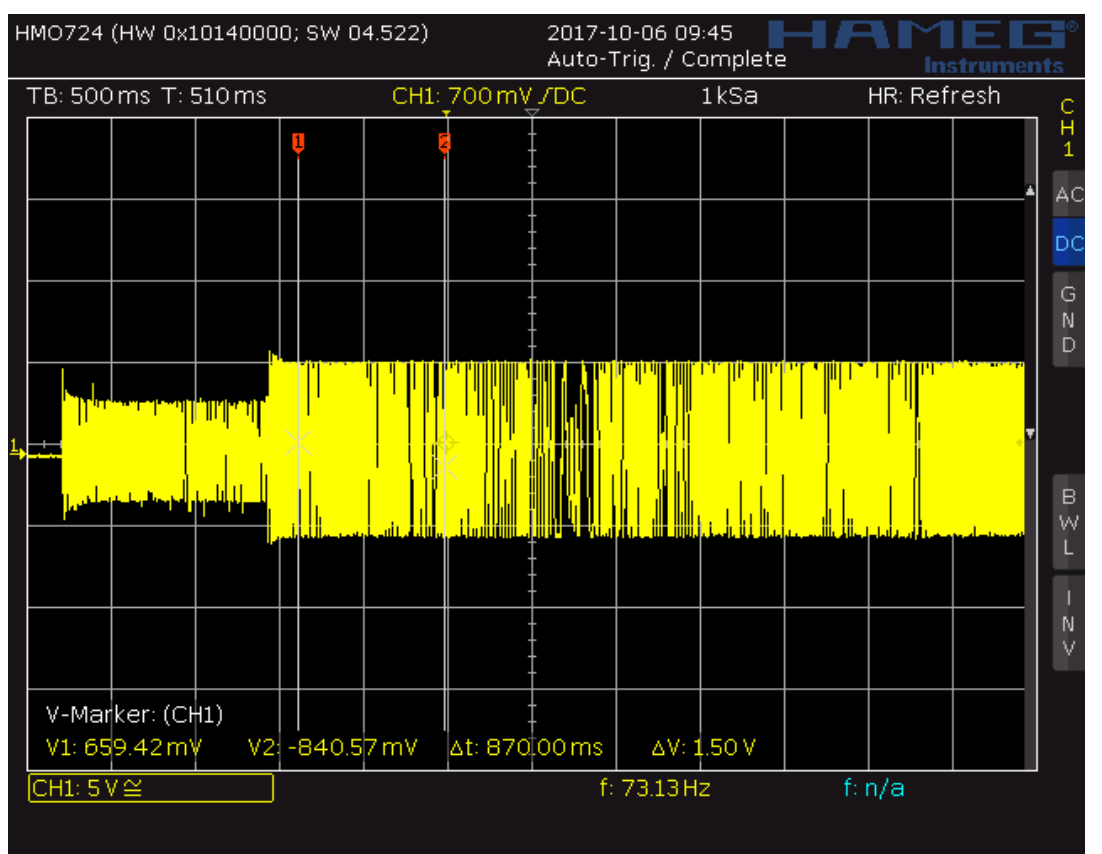

Fig. 4 Measurement of time courses for the sending end by a control signal

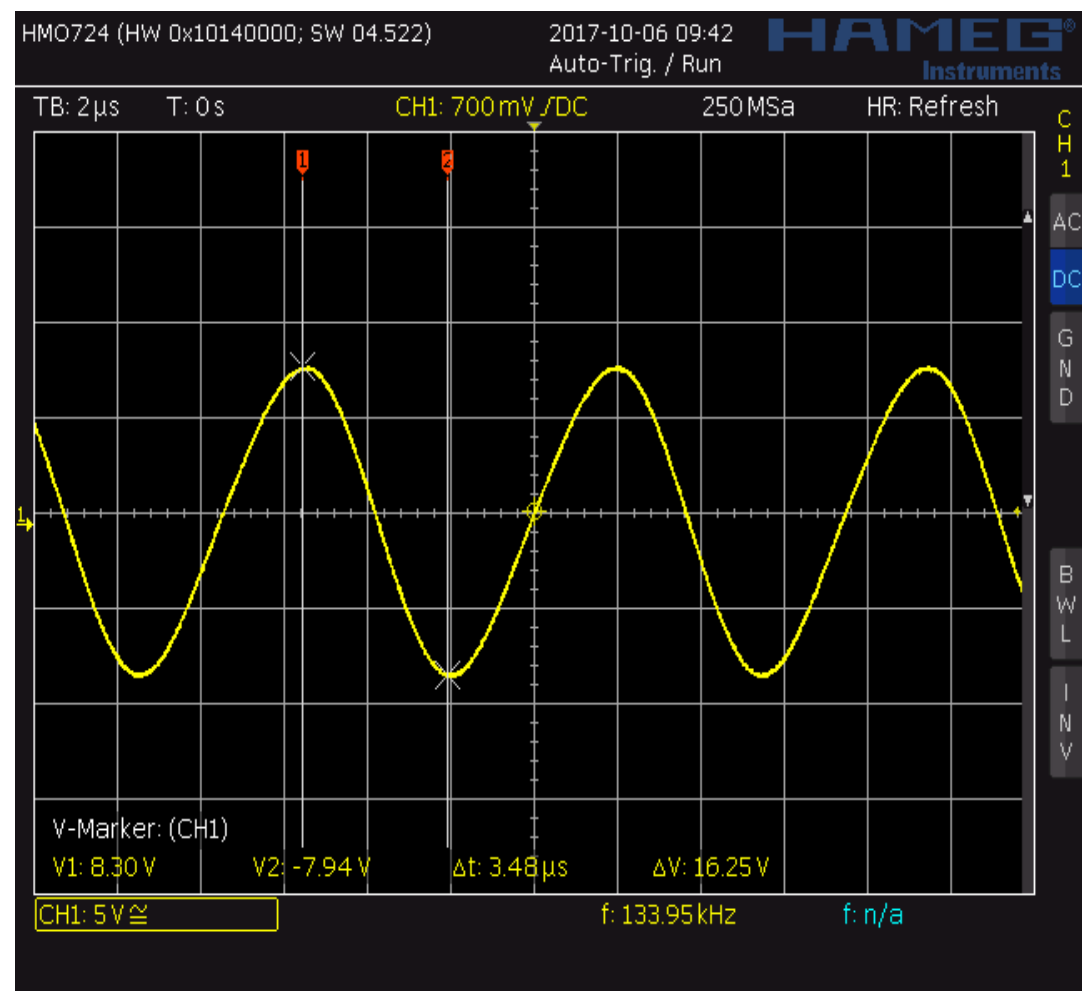

Fig. 5 Measurement of time courses for the sending end by a control signal maintaining the $9 \mathrm{~V}$ power supply

\section{CONCLUSION}

Currently, higher expectations are being set for the mining industry although the current state of the art does not always allow the introduction of an innovative solution to previously operated control systems. New technical challenges are being developed by mining machinery manufacturers, which arise from the real needs of users. The article presents preliminary results of research on a laboratory electrohydraulic control system for use in an innovative control 
system of a longwall control system. The conducted research analysis is to enable determination of the applicability in industrial conditions. The preliminary results show that the system is able to transmit energy with specific parameters. The obtained values may be of fundamental importance for the application of the control system in high-efficiency longwall complexes. The analysis of the test results was carried out in terms of the assessment of performance for an innovative electrohydraulic control system for the powered roof support. According to the author, the presented solution can be of key importance for the development of electrohydraulic systems for controlling a powered roof support. The presented characteristics and waveforms show that a good agreement between the theoretical analysis and the experimental results from the laboratory model was obtained. Discrepancies in the results obtained are mainly due to the inaccuracy of the measurement. The paper presents a preliminary research analysis on the possibility of obtaining adequate energy for performing work in the electrohydraulic control system of the roof support. The obtained results indicate that the system is able to transmit energy at a specific level, also in the case of its dynamically changing parameters. For practical applications of the system, it is necessary to extend the work analysis by optimizing the geometrical shape of the coils and taking into account the influence of structural ferromagnetic and conductive elements constituting the environmental environment of the coil system. In order to reduce the disturbances of electromagnetic immunity and to reduce the value of high-frequency eddy currents induced in the structure, it is necessary to use a ferrite screen concentrating electromagnetic field. The presented test results should be considered as preliminary. The usefulness and reliability of the tested system can be only confirmed by applying it into the electronic control system for the powered roof support.

\section{ACKNOWLEDGEMENTS}

The work was carried out within the project 'Innovative electrohydraulic control system for powered roof support' No. POIR.01.01.01-00-1129/15. Intelligent Development Operational Programme 2014-2020 carried out by the National Centre for Research and Development.

\section{REFERENCES}

Brodny, J. and Tutak, M. (2016). Determination of the zone endangered by methane explosion in goaf with caving of operating longwalls. $16^{\text {th }}$ International Multidisciplinary Scientific SGEM Conference Proceedings, Book 1 Vol. 2, pp. 299-306. DOI:10.5593/SGEM2016/B12/S03.039

Brodny, J. and Tutak, M. (2018a). Determination of the Zone with a Particularly High Risk of Endogenous Fires in the Goaves of a Longwall with Caving. Journal of Applied Fluid Mechanics, Vol. 11, No. 3, pp. 545-553. DOI: 10.18869/acadpub.jafm.73.246.27240

Dyrektywa, (2006): Dyrektywa 2006/42/WE Parlamentu Europejskie i Rady z dnia 17 maja 2006 r. w sprawie maszyn, zmieniająca dyrektywę 95/16/WE. Dziennik Urzędowy Unii Europejskiej L157/24. 
Figiel, A. (2014). Bezpieczeństwo funkcjonalne układów sterowania maszyn górniczych. [Functional safety of mining machine control systems]. Maszyny Górnicze, vol 4, pp. 33-39.

PN-EN 62061:2008P+A1:2013-6E Safety of machinery - Functional safety of safetyrelated electrical, electronic and programmable electronic control systems.

PN-EN 61508 Functional safety of electrical / electronic / programmable electronic safety related systems.

PN-EN ISO 13849-1:2008. Safety of machinery. Safety related parts of control systems. Part 1: General principles for design.

PN-EN 62061:2008. Safety of machinery. Functional safety of safety-related electrical, electronic and programmable electronic control systems.

Kasprusz, A. Mikuła, S. Wojtas, M. (2013). Sterowanie elektrohydrauliczne DOH-matic do automatyzacji pracy obudowy zmechanizowanej, Wiadomości Górnicze nr 5.

Krauze, K. (2012). Urabianie skał strugami statycznymi. Podstawy doboru i projektowania kompleksów strugowych. Wydaw. Śląsk, Katowice.

Szurgacz, D. (2018). Analysis Characteristics determination of electrohydraulic control system operation to reduce the operation time of a powered roof support, E3S Web of Conferences 29, 00007 XVIt ${ }^{\text {th }}$ Conferences of PhD Students and Young Scientist doi.org/10.1051/e3sconf/20182900006

Szurgacz, D. and Brodny, J. (2018). Dynamic resistance test for safety valve in electro hydraulic control system for powered roof supports, $18^{\text {th }}$ International multidisciplinary scientific geoconference SGEM 2018, 2 July-8 July, 2018, Albena, Bulgaria. Conference proceedings Volume 18. Science and technologies in geology, Exploration and Mining, Issue 1.3. pp. 343-350. doi.org/10.5593/sgem2018/1.3

Tutak. M, and Brodny, J. (2019). Predicting Methane Concentration in Longwall Regions Using Artificial Neural Networks. Inernational Journal Environmental Research Public Health 16, 1406; pp. 1-22. doi:10.3390/ijerph16081406

Tutak. M, and Brodny, J. (2018b). Analysis of the Impact of Auxiliary Ventilation Equipment on the Distribution and Concentration of Methane in the Tailgate. Energies 11(11), 3076, pp. 1-28. https://doi.org/10.3390/en11113076

WUG, (2018). Ocena stanu bezpieczeństwa pracy, ratownictwa górniczego oraz bezpieczeństwa powszechnego w związku z działalnością górniczo-geologiczną w 2018 roku.

\begin{abstract}
.
In the era of Industry 4.0, coal companies began to reach for new innovative technologies that increase work safety and their possible use affects the economic improvement of companies. One of them is to equip a powered roof support section with an electrohydraulic control system with a monitoring system that tracks operating parameters. The development of a monitoring system for a powered roof support is a key investment in new longwall complexes. It allows rapid diagnostics of status of the support. Currently used system designed to control the powered roof support are based on blocks of manually controlled distributors. The pilot control is currently the leading control that properly functions in all conditions, allowing to adapt to the requirements resulting from the construction of the section. A number of tests and analyses must be conducted prior to introducing the new control based on an innovative approach into operation. The basic research has focused on identifying the user interface that will potentially be the solution for the entire system. The user has defined how the driver should look like and how it will be operated and maintained. The results of the first series of tests on the elements of an innovative electronic control system of the powered roof support enabled to develop a prototype version. The assumptions for the system were verified during the conducted development studies. The article presents preliminary results of development research for devices included in the innovative control system of the powered roof support.
\end{abstract}

Keywords: fire hazards, powered roof support, natural hazard, nitrogen cushion 